九州大学学術情報リポジトリ

Kyushu University Institutional Repository

\title{
Genetic Control of Some Morphological and Physiological Characters in Lablab Bean (Lablab purpureus (L...) Sweet)
}

\section{Sultana, Nasreen}

Laboratory of Horticultural Science, Division of Agricultural Botany, Department of Plant Resources, Graduate School of Bioresource and Bioenvironmental Sciences, Kyushu University

Ozaki, Yukio

Laboratory of horticultural Science, Division of Agricultural Botany, Department of Plant Resources, Faculty of Agriculture, Kyushu University

Okubo, Hiroshi

Laboratory of horticultural Science, Division of Agricultural Botany, Department of Plant Resources, Faculty of Agriculture, Kyushu University

https://doi.org/10.5109/24420

出版情報：九州大学大学院農学研究院紀要. 46 (1)，pp. 39-46，2001-10-30. Kyushu University バージョン：

権利関係 : 


\title{
Genetic Control of Some Morphological and Physiological Characters in Lablab Bean (Lablab purpureus (L.) Sweet)
}

\author{
Nasreen SULTANA*, Yukio OZAKI and Hiroshi OKUBO \\ Laboratory of Horticultural Science, Division of Agricultural Botany, Department of Plant Resources, \\ Faculty of Agriculture, Kyushu University, Fukuoka 812-8581, Japan \\ (Received June 13, 2001 and accepted July 11, 2001)
}

\begin{abstract}
Inheritance of growth habit, photoperiod sensitivity, pigmentation on stem and petal in lablab bean was studied. Monogenic control of growth habit was revealed from different $\mathrm{F}_{2}$ segregating families derived from the crosses between determinate and indeterminate accessions. Although the determinate character seemed to be controlled by one locus from the crosses between wild and determinate types, inheritance of the growth habit could not be clarified because of the appearance of extreme dwarf plants and determinate plants with indeterminate lateral shoots. From the same cross photosensitivity and pigmentation on stem displayed to be governed by respective two loci. This is the first report on complementary gene control of photoperiod sensitivity in lablab bean. From the crosses between determinate and indeterminate types pigmentation on stem was controlled by three loci. Petal color was observed as governing by two loci; complementary gene action.
\end{abstract}

\section{INTRODUCTION}

Systematic improvement of lablab bean is limited (Rashid, 1993; Shivashankar et al., 1993). Growth habit, pigmentation on different parts (stem, petiole, petal, sepal, pod and seed coat), pod and seed characters (number, weight, texture, size, shape and color), sensitivity to photoperiod and tolerance to diseases and insect pests are important morphological and physiological characters that could serve as effective selection criteria for improvement of this crop. The major objectives in lablab bean breeding are the development of determinate bush type, photo-insensitivity (year round and early maturity type), soft textured long pod (for vegetables), large seeds (for pulses), tolerance to insect pests (fruit borer, red mite and aphids) and wide adaptability (suitable for hot and cold weather).

The genetic control of many of the above-mentioned characters is not known. In the present paper, genetic control of growth habit, photoperiod sensitivity and pigmentation on stem and petal was described using $\mathrm{F}_{2}$ segregating families.

\section{MATERIALS AND METHODS}

Origin and characters of the parents are presented in Table 1 . The highly photoperiod sensitive accessions 60216 (wild, from Uganda) and 52510 (wild, from Zimbabwe) were

\footnotetext{
* Laboratory of Horticultural Science, Division of Agricultural Botany, Department of Plant Resources, Graduate School of Bioresource and Bioenvironmental Sciences, Kyushu University

* Corresponding author
} 
placed in the growth chamber $\left(25^{\circ} \mathrm{C}, 70 \% \mathrm{RH}\right.$ and $12-\mathrm{h}$ daylength) for flowering. Because these wild types did not flower in a plastic house of Kyushu condition or in the phytotron $\left(25 \pm 2{ }^{\circ} \mathrm{C}, 70 \pm 5 \% \mathrm{RH}\right.$ and natural daylength) of Biotron Institute, Kyushu University. The photosensitive accession Tot-2456 (Thailand) was placed in $25^{\circ} \mathrm{C}$ phytotron and was covered from 5:30 p.m. to 9:00 a.m. of the following day. This accession flowers outside in short day of winter season but no viable pollen was found in this condition probably due to low temperature. All other accessions were grown in the plastic house for all the year round.

Reciprocal crosses were made between determinate accession and all other eleven accessions. No fruit setting was observed in the crosses between the determinate and 52510 in both directions of. Only one way successful crosses were observed in between the determinate with 60216 and with 34777 . In both cases the determinate accession was used as pollen parent.

Reciprocal crosses were also made between 60216 and 52510, between Akabana and 52510 and between Tot-2456 and 60216 . Fruit setting was observed in one way crosses between 52510 and 60216, and between 52510 and Akabana, when 52510 was used as pollen parents. In all other combinations fruit setting was observed in both way crosses. In each cross, 10 to 30 flowers were used except the accession 52510 due to poor flowering.

Seeds of the determinate and Akabana (10 individuals each), $10 \mathrm{~F}_{1}$ 's from both way crosses between them and $F_{2}$ progenies (derived from each of a single $F_{1}$ plant) were sown in $12 \mathrm{~cm}$ diameter plastic pots containing a mixture of pumice : vermiculite : sand $(1: 1: 1, \mathrm{v} / \mathrm{v} / \mathrm{v})$. They were then placed in $20^{\circ} \mathrm{C}$ and $25^{\circ} \mathrm{C}$ in the phytotron for the period of June to September 1999 and November 1999 to January 2000. $F_{2}$ progenies derived from

Table 1. Origin and characters of parental genotypes of lablab bean under study.

\begin{tabular}{|c|c|c|c|c|c|}
\hline \multirow{2}{*}{ Accession } & \multirow{2}{*}{ Origin } & \multirow{2}{*}{$\begin{array}{l}\text { Growth } \\
\text { habit: }\end{array}$} & \multicolumn{2}{|c|}{ Pigmentation $^{y}$ on } & \multirow{2}{*}{$\begin{array}{l}\text { Response to } \\
\text { photoperiod }^{x}\end{array}$} \\
\hline & & & petal & stem & \\
\hline Determinate & India & D (bush) & $\mathrm{W}$ & G & IS \\
\hline Akabana & Japan & I (SV) & $\mathrm{P}$ & $\mathrm{P}$ & IS \\
\hline 60216 & Uganda & I (LSV) & $R P$ & $\mathrm{P}$ & HS \\
\hline 52510 & Zimbabwe & I (LSV) & $\mathrm{RP}$ & $\mathrm{P}$ & HS \\
\hline Tot-2456 & Thailand & I (LSV) & LP & $L P G$ & $\mathrm{~S}$ \\
\hline 34777 & India & I (SV) & W & $\mathrm{G}$ & LS \\
\hline $52504 \mathrm{~A}$ & Angola & I (SV) & LP & $M$ & LS \\
\hline 52532 & India & I (SV) & W & $\mathrm{G}$ & LS \\
\hline $52506 \mathrm{~B}$ & Angola & $\mathrm{I}(\mathrm{SV})$ & LP & M & LS \\
\hline 76998 & Zambia & I (MSV) & W & $\mathrm{G}$ & $\mathrm{I} S \mathrm{~S}$ \\
\hline 34783 & India & I (MSV) & W & $\mathrm{G}$ & LS \\
\hline 36903 & USSR & I (MSV) & $\mathrm{P}$ & M & LS \\
\hline
\end{tabular}

${ }^{2} \mathrm{D}$; Determinate, I; Indeterminate, SV; Small vine, MSV; Medium spreading vine, LSV; Large spreading vine.

y W; White, P; Purple, RP; Reddish purple, LP; Light purple, G; Green, $\mathrm{LPG}=\mathrm{Light}$ green and purple, $\mathrm{M}$; Mixed (green and purple).

"IS; Insensitive, HS; Highly sensitive, S; Sensitive, LS; Less sensitive 
a single $F_{1}$ plant ( $60216 \times$ determinate) were grown in the plastic house from the period of September 2000 to January 2001. All other $F_{1} S$ were grown in a greenhouse and the plastic house.

Data were analyzed by the standard procedures. The $\chi^{2}$ test was applied to confirm the segregation ratios in $\mathrm{F}_{2}$ progenies.

\section{RESULTS AND DISCUSSION}

\section{Growth habit}

Growth habit of $86 \mathrm{~F}_{1} \mathrm{~s}$, derived from the crosses between the determinate and eleven other different indeterminate accessions is presented in Table 2. All the $F_{t} s$ irrespective of the direction of crosses, genotypes (cultivated or wild) or growing environment (plastic house, green house or phytotron and summer or winter season) were indeterminate in growth habit except one $F_{1}$ derived from the cross between 34777 (female) and the determinate (male). No successful reciprocal crosses obtained from this combination. Both parents were from Indian origin and no remarkable morphological, biochemical (isozymes) or molecular (RAPD) markers were identified except growth habit and seed shape (Sultana et al., 2000, 2001). The parent 34777 was indeterminate and its seed shape was oval, and the pollen parent was determinate in growth habit and produced round shaped seeds. From these results it is suggested that there are two indeterminate genes; one is dominant and the other is recessive to determinate gene.

In most cases, indeterminate growth habit was found dominant over determinate and controlled by a single gene pair with simple Mendelian inheritance. Some examples are reported in lablab bean (Harland, 1920), soybean (Bernard, 1971, 1972; Halvankar and Patil, 1994), pigeon pea (Gupta and Kapoor, 1991), chickpea (Rheenen et al., 1994), winged bean (Uemoto and Okubo, 1993), lima bean (Allard and Allard, 1953) and tomato (Yeager, 1927; Currence, 1933). In contrast, Hutchins (1940) found that determinate

Table 2. Growth habit of parents and $F_{1} s$ observed in some selected crosses.

\begin{tabular}{|c|c|c|c|c|}
\hline \multirow{2}{*}{ Cross } & \multirow{2}{*}{$\begin{array}{l}\text { Growth } \\
\text { habit }^{2}\end{array}$} & \multirow{2}{*}{$\begin{array}{l}\text { No. of } F_{1} S \\
\text { checked }\end{array}$} & \multicolumn{2}{|c|}{ Observed growth habit } \\
\hline & & & Determinate & Indeterminate \\
\hline Determinate $\times$ Akabana & $\mathrm{D} \times \mathrm{I}$ & 25 & 0 & 25 \\
\hline Akabana $\times$ Determinate & $\mathrm{I} \times \mathrm{D}$ & 25 & 0 & 25 \\
\hline Determinate $\times$ Tot -2456 & $\mathrm{D} \times \mathrm{I}$ & 10 & 0 & 10 \\
\hline Tot-2456 $\times$ Determinate & $I \times D$ & 10 & 0 & 10 \\
\hline $60216 \times$ Determinatc & $I \times D$ & 10 & 0 & 10 \\
\hline $34777 \times$ Determinate & $I \times D$ & 1 & 1 & 0 \\
\hline Determinate $\times 39078$ & $D \times I$ & 1 & 0 & 1 \\
\hline $52504 \mathrm{~A} \times$ Determinate & $\mathrm{I} \times \mathrm{D}$ & 1 & 0 & 1 \\
\hline $52532 \times$ Determinate & $I \times D$ & 1 & 0 & 1 \\
\hline Determinate $\times 52560 \mathrm{~B}$ & $\mathrm{D} \times \mathrm{I}$ & 1 & 0 & 1 \\
\hline Determinate $\times 76998$ & $\mathrm{D} \times \mathrm{I}$ & 1 & 0 & 1 \\
\hline Total & & 86 & 1 & 85 \\
\hline
\end{tabular}

${ }^{2} \mathrm{D}$; Determinate, I; Indeterminate. 
growth habit in cucumber is dominant over indeterminate and controlled by a single gene pair. Denna (1971) suggested that in cucumber most indeterminate cultivars possess a number of modifier genes and penetrance of the determinate character varied depending on the source of both the determinate and indeterminate parents.

Segregation and goodness of fit tests of eight $\mathrm{F}_{2}$ families derived from both way crosses between determinate and Akabana (each family derived from a single different $\mathrm{F}_{1}$ plant), grown in the controlled environment $\left(20\right.$ and $25^{\circ} \mathrm{C}$, phytotron) are presented in Table 3. All families segregated into a 3:1 ratio of indeterminate to determinate irrespective of growing temperature or season. The result suggests that determinate and indeterminate growth habit of lablab bean is controlled by a single gene pair and indeterminate growth habit is dominant over determinate.

Segregation and goodness of fit tests of growth habit, photoperiod sensitivity, pigmentation on stem and petal of $\mathrm{F}_{2}$ families derived from a cross between 60216 (female) and determinate (male) and both way crosses between Akabana and determinate are presented in Table 4. $\mathrm{F}_{2}$ plants from the cross between 60216 and determinate were grown in the plastic house in the period of September 2000 to January 2001 (non-inductive season for changing determinate plants to indeterminate, Kim et al., 1992). Among $125 \mathrm{~F}_{2}$ plants, 80 were indeterminate (viny), 25 were dwarf and determinate (flower at the tip of main stem), five were normal dwarf (dwarf but no flower), 10 were determinate (flower at the tip of main stem) with viny lateral branches and five were extreme dwarf (abnormal dwarf). The number of true indeterminate and determinate plants, 80 and 25, respectively, fits well to $3: 1$ ratio of indeterminate to determinate. Again it proved from this result that determinate and indeterminate growth habits of lablab bean are monogenic and indeterminate growth habit is dominant over determinate.

Inheritance of the growth habit could not be clarified in this study because of the appearance of extreme dwarf plants and determinate plants with indeterminate lateral shoots. The presence of extreme dwarf was also found in Phaseolus vulgaris. Nakayama (1957) reported abnormal dwarfness in garden bean (Phaseolus vulgaris) due to duplicate recessive gene $d w_{1} d w_{2}$. Lamprecht (1934) pointed out that in garden bean some indeterminates are relatively short. He suggested Fin and fin from finites for the

Table 3. Segregation and goodness-of-fit tests of growth habit of $F_{2}$ derived from the crosses between Akabana (indeterminate) and determinate grown in the phytotron in summer and winter seasons.

\begin{tabular}{|c|c|c|c|c|c|c|c|}
\hline \multirow{2}{*}{ Family } & \multirow{2}{*}{ Cross } & \multirow{2}{*}{$\begin{array}{l}\text { Growth condition } \\
\text { in the phytotron }\end{array}$} & \multicolumn{3}{|c|}{ No. of plants } & \multirow{2}{*}{$\chi^{2}(3: 1)$} & \multirow{2}{*}{$\mathrm{P}$} \\
\hline & & & Indeterminate & Determinate & Total & & \\
\hline 1 & Determinate $\times$ Akabana & Summer, $20^{\circ} \mathrm{C}$ & 31 & 9 & 40 & 0.03333 & 0.85513 \\
\hline $2 \mathrm{~A}$ & Akabana $\times$ Determinate & Summer, $20^{\circ} \mathrm{C}$ & 27 & 13 & 40 & 0.83333 & 0.36131 \\
\hline $3 \mathrm{D}$ & Determinate $\times$ Akabana & Summer, $25^{\circ} \mathrm{C}$ & 39 & 11 & 50 & 0.10667 & 0.74397 \\
\hline $4 \mathrm{~A}$ & Akabana $\times$ Determinate & Summer, $25^{\circ} \mathrm{C}$ & 35 & 15 & 50 & 0.42667 & 0.51363 \\
\hline $5 \mathrm{D}$ & Determinate $\times$ Akabana & Winter, $20^{\circ} \mathrm{C}$ & 39 & 11 & 50 & 0.10667 & 0.74397 \\
\hline $6 \mathrm{~A}$ & Akabana $\times$ Determinate & Winter, $20^{\circ} \mathrm{C}$ & 34 & 16 & 50 & 0.96 & 0.32719 \\
\hline $7 \mathrm{D}$ & Determinate $\times$ Akabana & Winter, $25^{\circ} \mathrm{C}$ & 44 & 11 & 55 & 0.49091 & 0.48352 \\
\hline $8 \mathrm{~A}$ & Akabana $\times$ Determinate & Winter, $25^{\circ} \mathrm{C}$ & 41 & 14 & 55 & 0.00606 & 0.93795 \\
\hline
\end{tabular}


Table 4. Characters of parents, $F_{1}$ and $F_{2}$ segregation for growth habit, photosensitivity and pigmentation on stem and petal.

\begin{tabular}{|c|c|c|c|c|c|c|c|c|c|c|c|c|}
\hline Characters & Cross & $\mathrm{F}_{1}$ & & $\mathrm{~F}_{2}$ & & & Ratio & $\chi^{2}$ & $\mathrm{P}$ & Ratio & $\chi^{2}$ & $\mathrm{P}$ \\
\hline \multirow[t]{4}{*}{ Growth habit ${ }^{2}$} & \multirow[t]{4}{*}{$\mathrm{P}_{1} \mathrm{IXP} \mathrm{P}_{2} \mathrm{D}$} & \multirow[t]{4}{*}{ I } & Dom. & I vs. Dr & I & 80 & $3: 1$ & 0.02857 & 0.86577 & $54: 10$ & 4.73235 & 0.0296 \\
\hline & & & \multirow{3}{*}{ Rec. } & & $\mathrm{D}$ & 25 & & & & & & \\
\hline & & & & Viny vs. Dwarf & Viny & 80 & $3: 1$ & 7.49067 & 0.0062 & $39: 25$ & 0.3226 & 0.54178 \\
\hline & & & & & Dwarf & 45 & & & & & & \\
\hline Photosensitivity ${ }^{x}$ & $\mathrm{P}_{1} \mathrm{HS} \times \mathrm{P}_{2} \mathrm{IS}$ & $\mathrm{SE}$ & Inter. & & IS & 66 & $3: 1$ & 31.6827 & 0.0000 & $9: 7$ & 0.47251 & 0.49184 \\
\hline & & & & & HS to SE & 59 & & & & & & \\
\hline \multirow[t]{3}{*}{$\begin{array}{l}\text { Pigmentation } \\
\text { on stem }^{\text {s }}\end{array}$} & $\mathrm{P}_{3}$ Purl. $\times \mathrm{P}_{2}$ Gr. & $\mathrm{PB}$ & Inter. & & $\begin{array}{l}\text { Purl. to PB } \\
\text { Gr. }\end{array}$ & $\begin{array}{r}168 \\
27\end{array}$ & $3: 1$ & 12.3504 & 0.00044 & $54: 10$ & 0.34283 & 0.5582 \\
\hline & $\mathrm{P}_{2} \mathrm{Gr} . \times \mathrm{P}_{3}$ Purl. & $\mathrm{PB}$ & Inter. & & Purl. to PB & 172 & $3: 1$ & 17.4376 & 0.0000 & $54: 10$ & 1.88904 & 0.16931 \\
\hline & $\mathrm{P}_{1}$ Purl. $\times \mathrm{P}_{2}$ Gr. & $\mathrm{PB}$ & Inter. & & $\begin{array}{l}\text { Gr. } \\
\text { Purl. to PB } \\
\text { Gr. }\end{array}$ & $\begin{array}{l}23 \\
62 \\
63\end{array}$ & $3: 1$ & 41.6667 & 0.0000 & $9: 7$ & 1.98413 & 0.15896 \\
\hline $\begin{array}{l}\text { Pigmentation } \\
\text { on petal }^{*}\end{array}$ & $\mathrm{P}_{2} \mathrm{~W} \times \mathrm{P}_{3}$ Purl. & $\mathrm{LP}$ & Inter. & & $\begin{array}{l}\text { Purl. to } L P \\
W\end{array}$ & $\begin{array}{l}54 \\
36\end{array}$ & $3: 1$ & 10.0148 & 0.00155 & $9: 7$ & 0.37319 & 0.54127 \\
\hline
\end{tabular}

${ }^{2} \mathrm{P}_{1} ; 60216$, wild (Uganda), $\mathrm{P}_{2}$; Determinate, cultivated (India), I; Indeterminate, D; Determinate, Dom.; Dominant, Rec.; Reccessive. ${ }^{y}$ Twenty of 125 were uncounted because of complexed expression of growth habit. ${ }^{x}$ HS; Highly sensitive (flower only in controlled condition), IS=Insensitive (flower all the year round except in extreme long day and high temperature), SE; Sensitive (flower only in short day), Inter.; Intermediate. ${ }^{\text {" }} \mathrm{P}_{3}$; Akabana, cultivated (Japan), Purl.; Purple, Gr.; Green, PB; Purple blotch on green stem. ' W; White, Purl.; Purple, LP; Light purple.

gene pair involved in determinate and indeterminate. Later, Rudorf (1958) designated $i^{+}$indeterminate and in determinate. Like garden bean, relatively short indeterminate accessions present in lablab bean (Sultana et al., 2001). The Indian accession 34777 was this kind of indeterminate. And the expression of determinate growth habit in $\mathrm{F}_{1}$ between 34777 and the determinate might be explained in this way that there might be some interaction among modifier or inhibitory genes. Or the chromosome carrying determinate growth habit controlling genes might be preferentially transmitted in $F_{1}$ (preferential transmission was identified in lablab bean by Kundori et al. (2000)).

Ladizinsky (1997) conducted a series of intra- and inter-specific crosses in search of dwarfing gene in the genus Lens. He concluded that dwarf phenotype is controlled by two complementary genes, $\mathrm{Df}_{1}$ and $\mathrm{Df}_{2}$ and these two genes are suppressed by the dominant allele of dwarf inhibitory gene $D f i$. In fact, it revealed from the present experiment that the factors controlling growth habit, plant height and flowering or photoperiod sensitivity in lablab bean are related in a complex form.

\section{Photoperiod sensitivity}

Degree of photoperiod sensitivity expressed in $\mathrm{F}_{1}$ from the crosses between parents having different degrees of photoperiod sensitivity is presented in Table 5. Among ten cross combinations, $\mathrm{F}_{1} \mathrm{~S}$ from seven combinations were intermediate in respect to photoperiod sensitivity. $F_{1}$ S between HS (highly sensitive) and IS (insensitive) and between S (sensitive) and IS (insensitive) were all intermediate indicating that there is no complete dominance in this character. Due to the similar characters in other three 
Table 5. Response to photoperiod in parents and $\mathrm{F}_{1}$ s observed in some selected crosses.

\begin{tabular}{lll}
\hline \multirow{2}{*}{ Cross } & \multicolumn{2}{l}{$\begin{array}{l}\text { Degree of photoperiod } \\
\text { sensitivity }\end{array}$} \\
\cline { 2 - 3 } & in parents & in F plants \\
\hline $60216 \times$ Determinate & HS $\times$ IS & S to LS \\
Akabana $\times 52510$ & IS $\times$ HS & S to LS \\
$60216 \times 52510$ & HS $\times$ HS & HS \\
$60216 \times$ Tot-2456 & HS $\times$ S & S to HS \\
Tot-2456 $\times 60216$ & S $\times$ HS & S to HS \\
Akabana $\times$ Determinate & IS $\times$ IS & IS to LS \\
Determinate $\times$ Akabana & IS $\times$ IS & IS to LS \\
Tot-2456 $\times$ Determinate & S $\times$ IS & LS \\
Determinate $\times$ Tot-2456 & IS $\times S$ & LS \\
Determinate $\times 34773$ & IS $\times$ LS & LS \\
\hline
\end{tabular}

${ }^{z}$ IS; Insensitive to photoperiod (flower all the year round), LS; Less sensitive (flower twice a year), $\mathrm{S}$; Sensitive (flower only in very short day condition, HS=Highly sensitive (no flower at all in Kyushu).

combinations, character expression in $\mathrm{F}_{1} \mathrm{~S}$ in these combinations was not clear. Shanmugasundaram (1980) and Coyne (1966) reported that photoperiod sensitivity in soybean is controlled by polygenes. In contrast, Rao (1987) reported that photoperiod sensitivity in lablab bean is controlled by a single pair of gene.

Segregation of $\mathrm{F}_{2}$ progenies derived from a cross between 60216 (HS) and the determinate (IS) accessions, grown in short day conditions, is presented in Table 4. Among $125 \mathrm{~F}_{2}$ plants 66 flowered and 59 did not. The number of plants with flowering to non-flowering fits well in 9:7 ratio indicating the involvement of two pair of complementary genes for this character.

A close relationship between growth habit and photoperiod sensitivity was found in the genus Phaseolus (Rudorf, 1958). In Phaseolus indeterminate growth, fin $^{+}$, retards flowering as compared with fin. The $\mathrm{F}_{2}$ crosses between the indeterminate $\left(\right.$ fin $\left.^{+}\right)$short day (ne $u^{+}$, photo sensitive) Phaseolus aborigineus and the determinate (fin) day neutral (nue, photo insensitive) P. vulgaris gives 3:1 ratio when grown with a short photoperiod, but with long day segregates 9 indeterminate short day $\left(\mathrm{fin}^{+} n e \mathrm{u}^{+}\right): 3$ indeterminate day neutral (fin ${ }^{+}$neu): 4 determinate day neutral (fin neu ${ }^{+}$and neu). The third generation established that fin is epistatic to neu $u^{+}$. In the present study similar relationship was observed but the ratio was different. Among $125 \mathrm{~F}_{2}$ plants, 32 plants were indeterminate with flower, 48 were indeterminate but no flower, 25 were dwarf and flowered at the tip of main stem (determinate), five were dwarf but no flower (normal dwarf), 10 were determinate (flower at the tip of main stem) with viny lateral branch and five were extreme dwarf with no flower. It seems from the result that determinate growth habit and photoperiod sensitivity has close relationship in lablab bean and controlled by more than two loci and the degree of sensitivity is modified by some genes, but for clear recommendation it requires further studies.

According to Coyne (1966) photoperiodism in soybean is a complex trait and might 
be controlled by many genes. Some varieties may respond at only one or two loci while other varieties may differ at many loci. Under short day it appears that qualitative genes are not expressed and the variation expressed in segregating generation is mainly due to the action of polygenes and environment.

\section{Pigmentation on stem}

Stem color of $F_{1}$ from the crosses between green stem and green stem plants was green, that between purple stem and purple stem plants was purple and that between green stem and purple stem plants was all purple blotch (purple blotch on green stem). Stem color segregation was counted from $\mathrm{F}_{2}$ plants of the crosses between Akabana (purple stem) and determinate (green stem), grown in the phytotron. Among $195 \mathrm{~F}_{2}$ plants (Akabana $\times$ determinate), 168 were purple (both light and deep) and 27 were green. In the reciprocal cross, 178 plants had purple and 23 had green stem colors. The number of purple to green plants fitted well in 54:10 ratio of purple to green plants (Table 4), suggesting that pigmentation on stem is controlled by three loci. Rao (1987) inferred that pigmentation on stem was controlled by three dominant genes and the presence of any two of three genes caused the purple pigmentation in agreement with the present findings.

In another $\mathrm{F}_{2}$ family derived from the cross between 60216 and determinate, 62 plants showed purple stem color, whereas 63 plants were green. This number does not fit in 3:1 or 54:10 ratio but fits in 9:7 ratio, suggesting that this character is governed by two loci. Monogenic dominant gene action for stem color of lablab bean was reported by Raut and Patil (1985), while Nakahade et al. (1979) recorded digenic interaction. On the other hand Meenakshi and Sunderesan (1964) reported four genes controlling stem pigment in lablab bean.

\section{Pigmentation on petal}

All $F_{1} S$ between white petal color and white petal color plants produced white petal color plants, those between purple petal color and purple petal color plants showed purple and those between purple petal color and white petal color plants were all light purple. Segregation of $90 \mathrm{~F}_{2}$ plants was recorded from a cross between Akabana (purple petal) and determinate (white petal). Purple to light purple petal was observed in 54 plants and white petal was observed in 36 plants. The ratio of purple to white was $9: 7$ suggesting that petal color of lablab bean is controlled by two pairs of complementary genes, whereas Raut and Patil (1985) reported mongenic control of purple flower color. However, the result obtained in the present study was in full agreement with Harland (1920).

\section{REFERENCES}

Allard, H. A. and H. F. Allard 1953 Inheritance of four morphological characters in lima beans. IIilgardia, 22: 167-177 (cited from Yarnell, S. H. 1965 Cytogenetics of the vegetable crops. IV. Legumes. Bot. Rev., 31: 247-330)

Bernard, R. L. 1971 Two major genes for time of flowering and maturity in soybeans. Crop Sci., 11 : 242-244

Bernard, R. L. 1972 Two genes affecting stem termination in soybeans. Crop Sci., 12: 235-244

Coyne, D. P. 1966 The genetics of photoperiodism and the effect of temperature on the photoperiodic 
response for time of flowering in Phaseolus vulgaris L. varieties. Proc. Amer. Soc. Hort. Sci., 89: 350-360

Currence, T. M. 1933 Linkage relationships of growth habit in tomato plants. Proc. Amer. Soc. Hort. Sci., 29: 501-504

Denna, D. W. 1971 Expression of determinate growth in cucumbers (Cucumis sativus L.). J. Amer. Soc. Hort. Sci., 96: $277-279$

Gupta, S. C. and R. K. Kapoor 1991 Inheritance of growth habit in pigeonpea. Crop Sci., 31: 1456-1459

Halvankar, G. B. and V. P. Patil 1994 Inheritance and linkage studies in soybean. Indian J. Genet., 54: 216-224

Harland, H. C. 1920 Inheritance in Dolichos lablab L. Part I. Jour. Genet., 10: 219-226

Hutchins, A. E. 1940 Inheritance in the cucumber. J. Agri. Res., 60: 117-128

Kim, S. E., H. Okubo and Y. Kodama 1992 Growth response of dwarf lablab bean (Lablab purpureus (L.) Sweet) to sowing date and photoperiod. J. Japan. Soc. Hort. Sci., 61: 589-594

Kundori, V., I. D. Godwin and C. J. Liu 2000 Genetic mapping of the Lablab purpureus genome suggest the presence of 'cuckoo' gene (s) in this species. Theor. Appl. Genet., 100: 866-871

Ladizinsky, G. 1997 Dwarfing genes in the genus Lens Mill. Theor. Appl. Genet., 95: 1270-1273

Lamprecht, H. 1934 Zur Genetic von Phaseolus vulgaris X. Uber Infloreszenztypen und ihre Vererbung. Hereditas, 20: 71-93 (cited from Yarnell, S. H. 1965 Cytogenetics of the vegetable crops. IV. Legumes. Bot. Rev., 31: $247-330)$

Meenakshi, K. and R. Sunderesan 1964 Studies on inheritance of Dolichos lablab. Madras Agric. J., 51: 71 (cited from Rao, C. H. 1987 Genetic studies in garden bean. Indian J. Genet., 47: 347-350)

Nakahade, B. N., A. B. Deokar and R. D. Cruz 1979 Inheritance studies in Dolichos lablab (Roxb.) and (L.). J. Maharashtra Agric. Univ., 4: 262-265 (cited from Rao, C. H. 1987 Genetic studies in garden bean. Indian J. Genet., 47: 347-350)

Nakayama, R. 1957 Genetics studies of French beans. I. On the inheritance of abnormal dwarfness. Bull. Fac: Agr. Hirosaki Univ., 3: 26-29 (In Japanese)

Rao, C. H. 1987 Genetic studies in garden bean. Indian J. Genet., 47: 347-350

Rashid, M. M. 1993 Shabji Biggan. Bagla Academy, Dhaka (In Bengali)

Raut, V. M. and V. P. Patil 1985 Genetic studies in garden bean. J. Maharashtra Agric. Univ. 10: 292 (cited from Kallo, G. and S. C. Pandey 1993 Hyacinth bean. Lablab perpureus (L.) Sweet. In "Genetic Improvement of Vegetable Crops" ed. by G. Kallo and B. O. Bergh, Pergamon Press, Oxford, pp. 387-389)

Rheenen, H. A., R. P. S. Pundir and J. H. Miranda 1994 Induction and inheritance of determinate growth habit in chickpea (Cicer arietinum L.). Euphytica, 78: 137-141

Rudorf, W. 1958 Genetics of Phaseolus aborigineus Burkart. Proc. X Intern. Cong. Genet., 2: 243 (cited from Yarnell, S. H. 1965 Cytogenetics of the vegetable crops. N. Legumes. Bot. Rev., 31: 247-330)

Shanmugasundaram, S. 1980 Varietal Differences and Genetic Behaviour for the Photoperiodic Response in Soybeans. Ph. D. thesis, Kyushu University, Fukuoka

Shivashankar, G., R. S. Kulkarni, H. E. Shashidhar and D. M. Mahishi 1993 Improvement of Ficld Bean. In "Advances in Horticulture Vol. 5. Vegetable Crops", ed. by K. L. Chandha and G. Kallo, New Delhi, pp. 277-286

Sultana, N., Y. Ozaki and H. Okubo 2000 The use of RAPD markers in lablab bean (Lablab purpureus (L.) Sweet) phylogeny. Bull. Inst. Trop. Agr., Kyushu Univ., 23: 45-51

Sultana, N., Y. Ozaki and H. Okubo 2001 Morphological and physiological variation in lablab bean (Lablab purpureus (L.) Sweet). J. Fac. Agr., Kyushu Univ., 45: 465-472

Uemoto, S. and H. Okubo 1993 'Chikuhime', a dwarf and new semi dwarf cultivars. In "Winged Bean and Some Other Vegetables and Medicinal Plants in the Tropics and Subtropics", ed. by H. Okubo, Nihon Tokushu Nousanbutsu Kyoukai, Tokyo, pp. 55-63

Yeager, A. F. 1927 Determinate growth in the tomato. J. Hered, 18: 263-265 